\title{
Sexual dimorphism in the osteoarthritis of STR/ort mice may be linked to articular cytokines
}

\author{
S Mahr, J Menard, V Krenn, B Müller
}

Ann Rheum Dis 2003;62:1234-1237. doi: 10.1136/ard.2002.005041

Background: STR/ort mice spontaneously develop degenerative changes of the knee joints resembling human osteoarthritis $(\mathrm{OA})$, with the males being more severely affected than the females.

Objective: To analyse the early changes leading to OA by examining the articular cytokine expression and degenerative changes in STR/ort mice.

Methods: 122 STR/ort mice of both sexes aged between 2 and 15.5 months were included. Thin sections of the knees were analysed for osteoarthritic changes by haematoxylin/ eosin staining. The articular cytokine expression was investigated by immunohistochemical staining using monoclonal antibodies specific for interleukin (IL)6, tumour necrosis factor $\alpha$, transforming growth factor $\beta 1$ (TGF $\beta 1$ ), ILI $\beta$, IL4, and IL10, respectively.

Results: Both cartilage degeneration and articular cytokine expression differ between the sexes. The protection from cartilage degeneration in the female mice correlates with an increased expression of TGF $\beta 1$ and IL 4 at 2 months of age. Conclusion: The increased expression of TGF $\beta 1$ and IL 4 in young STR/ort female mice suggests that the sexual dimorphism is mediated through the articular expression of cytokines involved in cartilage metabolism.

O steoarthritis (OA) is a degenerative joint disease of unknown cause. The balance between cartilage degradation and synthesis-finely tuned in the healthy-is disturbed in OA, resulting in the complete loss of articular cartilage. ${ }^{1}$ The chondrocytes themselves produce the cytokines and growth factors known to be involved in cartilage metabolism. While the transforming growth factor $\beta 1$ (TGF $\beta 1$ ) stimulates new cartilage formation, ${ }^{2}$ tumour necrosis factor $\alpha(\mathrm{TNF} \alpha)$ and interleukin $1 \beta$ (ILI $\beta)$ inhibit proteoglycan synthesis. ${ }^{3}$ In vitro, TGF $\beta 1$, IL4, and ILl0 can prevent and reverse cartilage degradation. ${ }^{4}$

We have previously shown that the cytokines and growth factors supporting cartilage degradation are up regulated in OA chondrocytes analysed at the end stage of the disease. ${ }^{5}$ To correlate the cytokine expression and the onset of degenerative changes leading to OA, early stages of the disease need to be analysed. However, by the time human OA joints become available for sampling, it is difficult to differentiate between the cause and consequence of the disease. Therefore, we turned to the STR/ort mouse, which spontaneously develops degenerative changes of the knee joint resembling human OA. ${ }^{67}$ Interestingly, female STR/ort mice develop only mild OA, whereas $85 \%$ of the 35 week old males show extensive OA-like lesions. ${ }^{6}$ We here analyse STR/ort mice between 2 and 15.5 months of age for the sex-specific course of disease and the articular cytokine expression.

\section{MATERIALS AND METHODS \\ Mice}

STR/ort mice were purchased from Harlan Winkelmann, Borchen, Germany. A total of 60 male and 62 female STR/ort mice were analysed and were killed at two different times, five months apart. The first cohort included 55, the second 67 mice. At each time, between two and four mice of each sex and cohort were killed. BALB/c mice aged 2 and 12 months served as controls.

\section{Histology}

Both knees of each mouse were prepared, thin sections were cut in an anterior to posterior direction and analysed for osteoarthritic changes by haematoxylin and eosin staining. The specimens were graded as follows: grade 0, healthy cartilage; grade 1, irregularities of the cartilaginous surface; grade 2, fissural ulcerations; grade 3, complete loss of articular cartilage with the subchondral bone being exposed. Both knees of two to four male and female STR/ort mice in each age group and cohort were analysed. The degradations of the medial and lateral tibial plateaux and femoral condyles were graded (grades $0-3$ ), and the grades added up for both knees. The maximum score possible for each mouse is thus 24. Means were calculated for the various age and sex groups.

\section{Immunohistochemistry}

Cytokine expression of articular chondrocytes was assessed in the knees of 2, 3.5, and 10.5 month old STR/ort mice. Two month old BALB/c mice were used as controls. Immunohistochemical staining was performed using monoclonal antibodies recognising IL6, TNF $\alpha$, TGF $\beta 1$, IL1 $\beta$, IL4, and IL10. Three to four STR/ort mice were analysed in each age and sex group, the total numbers of articular chondrocytes in each thin section were counted, and the percentage of positive cells calculated. Staining with the primary monoclonal antibody omitted served as a control.

\section{Statistical analysis}

A Mann-Whitney test was performed to calculate the differences between the medians of cytokine producing chondrocytes in mice of different ages and sexes. All knee joints analysed were considered individually in this calculation.

\section{RESULTS}

Cartilage degeneration starts earlier and is more severe in male STR/ort mice

Whereas in female mice the onset of OA did not begin before 4.5 months of age, the first signs of OA started between 2 and 3.5 months of age in the males, and more severe grades of

Abbreviations: IL, interleukin; OA, osteoarthritis; TGF $\beta 1$, transforming growth factor $\beta 1$; TNF $\alpha$, tumour necrosis factor $\alpha$ 

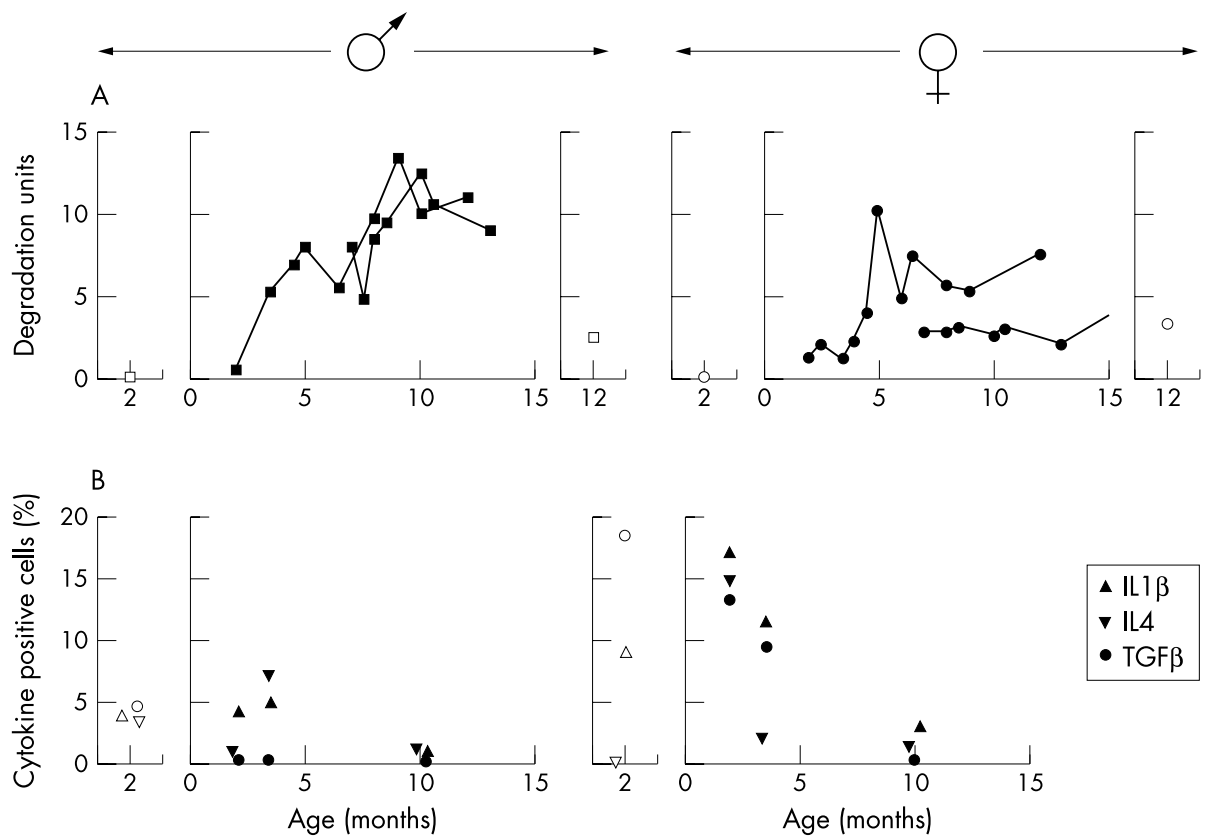

$\Delta$ IL $1 \beta$

$\nabla$ IL4

- TGF $\beta$ 15

Figure 1 Male and female STR/ort mice differ in the severity of OA and in the articular cytokine expression. Cartilage degradation and cytokine expression pattern from male (left panels) and female mice (right panels) are shown. Data from STR/ort mice are shown as filled symbols, data from $\mathrm{BALB} / \mathrm{c}$ mice are shown as open symbols to the left and to the right of the STR/ort data, respectively. (A) Degradation of the articular cartilage. Squares (males) and circles (females) resemble the course of degenerative changes and show the mean grades of cartilage degradation. (B) Cytokine expression patterns of the articular chondrocytes. The medians of the percentages of chondrocytes stained positive for the expression of ILI $\beta$, IL4, and TGF $\beta 1$ are shown.

joint destruction were reached (fig lA). In general the medial sides of the knee joints were more severely affected than the lateral ones. Interestingly, both of the male cohorts showed almost identical courses of disease, whereas the degree of cartilage degeneration differed in the two female cohorts. BALB/c mice only developed mild osteoarthritic changes and only at the age of 12 months.

\section{Articular cytokine expression in male and female mice shows different patterns}

The most dramatic differences were seen for ILl $\beta$, IL4, and TGF $\beta 1$ at 2 months of age. Whereas the articular chondrocytes of male BALB/C and STR/ort mice showed only mild expression of TGF $\beta 1$, ILI $\beta$, and IL4, chondrocytes from age matched female mice showed a marked increase (fig 1B). In STR/ort mice, the differences between males and females was significant, with $\mathrm{p}$ values of 0.006 for TGF $\beta 1$ and of 0.042 for IL4. The difference for ILl $\beta$ did not quite reach significance (table 1). Figure 2 shows examples of staining performed with TGF $\beta 1-$ and ILI $\beta$ specific antibodies.

At 3.5 months of age, the articular cytokine expression slowly declined in both sexes, with the exception of IL4 in the males (fig 1B). Interestingly, there was a statistically significant increase in $\mathrm{TNF} \alpha$ positive chondrocytes in male STR/ort mice at 3.5 months of age, with a corresponding $\mathrm{p}$ value of 0.026 (table 1). At 10.5 months of age, all the cytokines analysed were reduced, and the reduction ranged between 1.4- and 8.2-fold (fig 1B). No positive cells were seen in any of the control stainings. With the exception of ILl $\beta$ in the 2 month old male mice, the cytokine expression was more pronounced on the lateral sides of the joints.

\section{DISCUSSION}

Two unexpected findings emerge from this study, the first one being the increased expression of ILl $\beta$, TGF $\beta 1$, and IL4 in young female mice. A previous study showing that TGF $\beta 1$ combined with IL4 is chondroprotective in in vitro experiments $^{4}$ is in line with our observation in STR/ort mice. We therefore suggest that an early peak of TGF $\beta 1$ and IL4 in the female mice mediates the protective effect, preventing and/or delaying the degenerative changes observed in the males. The correlation between increased cytokine expression and reduced cartilage degeneration at the lateral sides of the joints supports this idea (table 1). Even though our results support the importance of cytokines for cartilage metabolism, the role of IL1 $\beta$ remains obscure. On the one hand, ILI $\beta$ is among the three cytokines up regulated in young STR/ort females being protected from OA. On the other, ILI $\beta$ is known as a potent mediator of cartilage degradation. $^{3}$ However, TGF $\beta 1$ combined with IL4 has in vitro been shown to be chondroprotective. ${ }^{4}$ We therefore suggest that the early peak of TGF $\beta 1$ and IL4 protects the cartilage of female mice and thereby contributes to the reduced severity of OA.

The differences in articular cytokine expression between male and female STR/ort mice are also reflected in BALB/C mice which do not develop OA. However, the varying incidence and severity of OA in STR/ort mice as well as the sexual dimorphism already indicate a multifactorial disease. Quite likely, the BALB/C background lacks the genetic predisposition responsible for the induction of OA in STR/ ort mice.

Our results suggest that articular cytokines play a part in mediating the sexual dimorphism in the OA of STR/ort mice. At 2 months of age, sexual maturity is at its peak in the females and an impact of hormones on the cytokine expression is intriguing. Two of the most prominent hormones regulating cartilage generation and regeneration are oestrogens and leptin, and receptors for both of them are expressed on articular chondrocytes. ${ }^{89}$ Likewise, bone metabolism has been shown to be regulated by oestrogens and here, the effect is thought to be mediated by $\operatorname{ILl} \beta .^{810} \operatorname{ILl} \beta$ in 


\begin{tabular}{|c|c|c|c|c|c|}
\hline \multirow[b]{2}{*}{ Cytokine } & \multirow[b]{2}{*}{ Mouse strain } & \multirow[b]{2}{*}{ Sex } & \multirow[b]{2}{*}{ Age (months) } & \multicolumn{2}{|c|}{ \% Positive chondrocytes (medians) } \\
\hline & & & & Medial & Lateral \\
\hline \multirow[t]{8}{*}{ IL1 $\beta$} & \multirow[t]{6}{*}{ STR/ort } & \multirow[t]{3}{*}{ Male } & 2.0 & 5.0 & 2.5 \\
\hline & & & 3.5 & 2.0 & 7.6 \\
\hline & & & 10.5 & 0 & 0.3 \\
\hline & & \multirow[t]{3}{*}{ Female } & 2.0 & 5.8 & 27.3 \\
\hline & & & 3.5 & 5.3 & 19.6 \\
\hline & & & 10.5 & 0 & 4.2 \\
\hline & \multirow[t]{2}{*}{$\mathrm{BALB} / \mathrm{c}$} & Male & 2.0 & 3.9 & 3.8 \\
\hline & & Female & 2.0 & 10.1 & 8.6 \\
\hline \multirow[t]{8}{*}{ IL4 } & \multirow[t]{6}{*}{ STR/ort } & \multirow[t]{3}{*}{ Male } & 2.0 & 0 & 0 \\
\hline & & & 3.5 & 6.1 & 7.1 \\
\hline & & & 10.5 & 0 & 0 \\
\hline & & \multirow[t]{3}{*}{ Female } & 2.0 & 3.4 & 27.9 \\
\hline & & & 3.5 & 0 & 2.1 \\
\hline & & & 10.5 & 0 & 0 \\
\hline & \multirow[t]{2}{*}{$\mathrm{BALB} / \mathrm{c}$} & Male & 2.0 & 2.8 & 4.1 \\
\hline & & Female & 2.0 & 0 & 0 \\
\hline \multirow[t]{8}{*}{ TGF $\beta 1$} & \multirow[t]{6}{*}{ STR/ort } & \multirow[t]{3}{*}{ Male } & 2.0 & 0 & 0 \\
\hline & & & 3.5 & 0 & 0 \\
\hline & & & 10.5 & 0 & 0 \\
\hline & & \multirow[t]{3}{*}{ Female } & 2.0 & 4.4 & 23.1 \\
\hline & & & 3.5 & 6.2 & 10.9 \\
\hline & & & 10.5 & 0 & 0.7 \\
\hline & \multirow{2}{*}{$\mathrm{BALB} / \mathrm{c}$} & Male & 2.0 & 5.4 & 3.9 \\
\hline & & Female & 2.0 & 14.2 & 24.0 \\
\hline \multirow[t]{8}{*}{ IL6 } & STR/ort & Male & 2.0 & 3.4 & 4.1 \\
\hline & & & 3.5 & 0.6 & 3.4 \\
\hline & & & 10.5 & 0 & 0 \\
\hline & & Female & 2.0 & 0 & 11.2 \\
\hline & & & 3.5 & 1.0 & 1.9 \\
\hline & & & 10.5 & 0 & 0 \\
\hline & $\mathrm{BALB} / \mathrm{c}$ & Male & 2.0 & 1.4 & 4.0 \\
\hline & & Female & 2.0 & 0 & 0 \\
\hline TNF $\alpha$ & STR/ort & Male & 2.0 & 0 & 0.9 \\
\hline & & & 3.5 & 0 & 8.1 \\
\hline & & & 10.5 & 0 & 0.3 \\
\hline & & Female & 2.0 & 0 & 9.4 \\
\hline & & & 3.5 & 0.4 & 0 \\
\hline & & & 10.5 & 0 & 1.4 \\
\hline & $\mathrm{BALB} / \mathrm{c}$ & Male & 2.0 & 5.0 & 2.6 \\
\hline & & Female & 2.0 & 1.5 & 1.4 \\
\hline IL10 & STR/ort & Male & 2.0 & 1.2 & 3.9 \\
\hline & & & 3.5 & 3.2 & 5.0 \\
\hline & & & 10.5 & 0 & 0 \\
\hline & & Female & 2.0 & 6.3 & 7.3 \\
\hline & & & 3.5 & 4.7 & 5.4 \\
\hline & & & 10.5 & 0 & 1.3 \\
\hline & $\mathrm{BALB} / \mathrm{c}$ & Male & 2.0 & 0.7 & 2.1 \\
\hline & & Female & 2.0 & 0.3 & 1.4 \\
\hline
\end{tabular}

articular chondrocytes has been described as stimulating the expression of both TGF $\beta 1$ and IL4. ${ }^{11}$ It is thus feasible that in the 2 month old female STR/ort mice, strong hormonal signalling results in increased ILI $\beta$ levels, leading to an increase in articular TGF $\beta 1$ and IL4. Likewise, for human OA, the rise in incidence and severity among postmenopausal female patients has been explained by the withdrawal of oestrogens, resulting in the loss of a cartilage protective effect. $^{812}$ In STR/ort mice a study with ovariectomised females suggests that oestrogens have only a minor role in the protection from OA, but larger numbers of animals will be required to reach firm conclusions. ${ }^{13}$ As of today, nothing is known about the role of leptin or of male sex hormones in murine OA.

The second interesting finding is the absence of articular cytokines in the old STR/ort mice. Our data are in agreement with previous data showing a marked decrease of articular cytokines in old mice at a late stage of the disease. ${ }^{14}$ Our results for the cytokine expression of 8-9 month old mice differ from those published previously. ${ }^{14}$ However, the published STR/ort colony was only mildly affected by OA, whereas in our mice all the 8-9 month old STR/ort males showed clear signs of OA. We conclude that the rapid decline of cytokine expression is connected with the rapid progression of $\mathrm{OA}$ in the males.

Collectively, our data focus attention on the role of hormones in regulating articular cytokine expression and thus regulating cartilage metabolism. Understanding the correlation between oestrogens, leptin and, possibly, additional hormones and the expression of ILI $\beta$, TGF $\beta 1$, and IL4 may further our understanding of degenerative bone and joint diseases. 

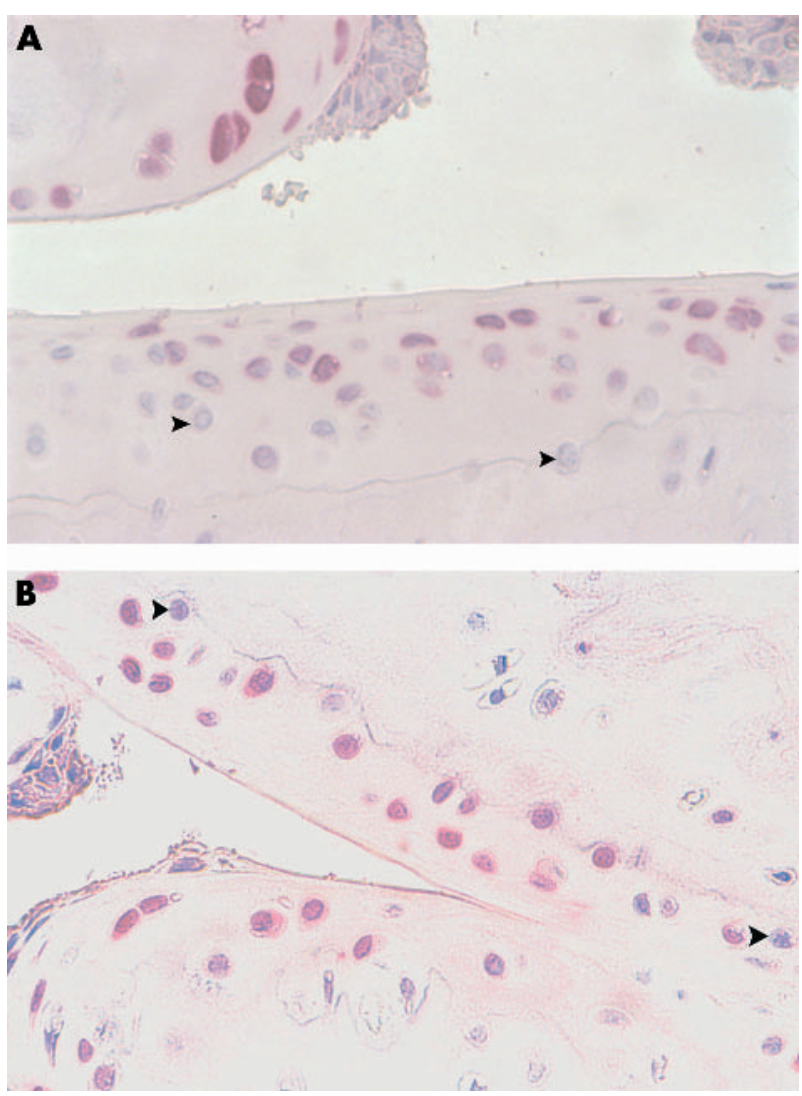

Figure 2 Cytokine expression in the articular cartilage of STR/ort mice. Thin sections of the knees of STR/ort mice were stained immunohistochemically for the presence of the different cytokines. Six hundredfold magnifications of thin sections stained for IL1 $\beta$ (A) and TGF $\beta 1$ (B) are shown. Examples for cytokine negative chondrocytes are indicated by black arrowheads.

\section{ACKNOWLEDGEMENTS}

We thank F Hardung for expert help with the histology and G Fernahl for her help in dehydrating the numerous specimens. This work was supported by grant Mu 844/4 from the DFG and the Berlin Senate for Research and Cultural affairs.
Authors' affiliations

S Mahr, J Menard, B Müller, Deutsches RheumaForschungs-Zentrum, Berlin, Germany

V Krenn, Institute for Pathology, Charité, Berlin, Germany

Correspondence to: Dr B Müller, Deutsches RheumaForschungs Zentrum Berlin, Schumannstr 21/22, 10117 Berlin, Germany; mueller@drfz.de

Accepted 15 March 2003

\section{REFERENCES}

1 Westacott $\mathrm{Cl}$, Sharif M. Cytokines in osteoarthritis: mediators or markers of joint destruction? Semin Arthritis Rheum 1996;25:254-72.

2 Lafeber FP, Vander Kraan PM, Huber-Bruning O, Vanden Berg WB, $\mathrm{Bij}$ lsma JW. Osteoarthritic human cartilage is more sensitive to transforming growth factor beta than is normal cartilage. $\mathrm{Br} J$ Rheumatol 1993:32:281-6.

3 van den Berg WB. Joint inflammation and cartilage destruction may occur uncoupled. Springer Semin Immunopathol 1998;20: 149-64.

4 van Roon JA, van Roy JL, Gmelig Meyling FH, Lafeber FP, Biilsma JW. Prevention and reversal of cartilage degradation in rheumatoid arthritis by interleukin-10 and interleukin-4. Arthritis Rheum 1996;39:829-35

5 Moos V, Fickert S, Müller B, Weber U, Sieper J. Immunohistochemical analysis of cytokine expression in human osteoarthritic and healthy cartilage. $J$ Rheumatol 1999;26:870-9.

6 Walton M. Degenerative joint disease in the mouse knee: histological observations. J Pathol 1977;123:109-22.

7 Mason RM, Chambers MG, Flannelly J, Gaffen JD, Dudhia J, Bayliss MT. The STR/ort mouse and its use as a model of osteoarthritis. Osteoarthritis Cartilage 2001;9:85-91

8 Felson DT, Nevitt MC. The effects of estrogen on osteoarthritis. Curr Opin Rheumatol 1998;10:269-72.

9 Figenschau Y, Knutsen G, Shahazeydi S, Johansen O, Sveinbjornsson B. Human articular chondrocytes express functional leptin receptors. Biochem Biophys Res Commun 2001;287:190-7.

10 Müller B. Cytokine imbalance in non-immunological chronic disease. Cytokine 2002; 18:334-9.

11 Moos V, Sieper J, Herzog V, Müller B. Regulation of expression of cytokines and growth factors in osteoarthritic cartilage explants. Clin Rheumatol 2001;20:353-8.

12 Wluka AE, Davis SR, Bailey M, Stuckey SL, Cicuttini FM. Users of oestrogen replacement therapy have more knee cartilage than non-users. Ann Rheum Dis 2001:60:332-6.

13 Chambers MG, Suri N, Cover P, Buckingham J, Visco D, Mason RM. Aggrecan degradation and osteoarthritis in STR/ort mice occur independently of sex and sex hormone status. 45th Annual Meeting, Orthopedic Society. Anaheim, CA, 1999:447.

14 Chambers MG, Bayliss MT, Mason RM. Chondrocyte cytokine and growth factor expression in murine osteoarthritis. Osteoarthritis Cartilage 1997;5:301-8 